DOI: $10.17976 / \mathrm{jpps} / 2017.05 .06$

\title{
ТЕОРЕТИКО-МЕТОДОЛОГИЧЕСКИЕ АСПЕКТЫ ИНСТИТУЦИОНАЛИЗАЦИИ ПОЛИТИЧЕСКИХ ЭЛИТ ПРИБАЛТИКИ
}

\author{
В.А. Смирнов
}

СМИРНОВ Вадим Анатольевич, кандидат политических наук, старший научный сотрудник Балтийского федерального университета им. И. Канта. Калининград. Для связи с автором: vsmirnov@ kantiana.ru

Смирнов В.А. Теоретико-методологические аспекты институционализации политических элит Прибалтики. - Полис. Политические исследования. 2017. № 5. C. 79-90. DOI: https://doi.org/10.17976/ jpps/2017.05.06

Статья поступила в редакцию: 30.01.2017. Принята к печати: 20.06.2017

\begin{abstract}
Аннотация. В статье рассматриваются теоретико-методологические основания анализа политических элит в странах Прибалтики с опорой на теорию малых стран и регионализма. Выявляются специфические черты формирования и развития властных групп в данном регионе. Ставится проблема теоретической связки между структурными и деятельностными аспектами при изучении политической элиты. Акцентируется проблематика связки внутриполитических и внешнеполитических факторов, влияющих на выбор решений политической элитой. В качестве одной из отправных точек выбрана теория малых стран, сквозь призму которой рассматриваются особенности развития властных групп в странах Прибалтики. Малые размеры государств обусловливают повышенную зависимость властных групп в Литве, Латвии и Эстонии от внешнеполитических факторов, своеобразных, используя терминологию Дж. Коломера, пространств-империй. Отдельное внимание уделяется изучению исторического фактора в формировании политических элит после выхода Прибалтики из состава СССР. В статье проблематизируется транзитологическая парадигма, преобладавшая в теоретических подходах к изучению политических элит в Прибалтике и Восточной Европе в целом. Помимо императивов трансформации режимов в направлении демократических идеалов следует учитывать императив борьбы властных групп за ресурсы во внутриполитической и внешнеполитической среде. Подчеркивается ряд противоречий, в том числе вывод миссий ОБСЕ из Латвии и Эстонии, развитие институтов политики памяти, криминализация отрицания “советской оккупации” как примеры решений элит на различных этапах становления текущих политических режимов в странах Прибалтики, не укладывающихся в рамки теории демократизации. Рассматриваются различные методы анализа элит Прибалтики; предлагается теоретическая рамка институционального регионализма как более эффективная для комплексного анализа структуры и действий властных групп в странах Прибалтики.
\end{abstract}

Ключевые слова: политическая элита; властные группы; политический институт; институционализация; структура; страны Прибалтики.

Рассматривая кейс политических элит прибалтийских государств, следует учесть, что речь идет о властных группах в малых странах, которые намного сильнее подвержены влиянию трансграничных процессов, нежели элиты крупных государств. Элиты малых стран в болышей степени зависят от внешнеполитических ресурсов - экономических, военных и культурных. Основная теоретическая проблематика заключается во включении малых стран в межгосударственные объединения или пространства-империи [Colomer 2007], которые могут обеспе- 
чить военный зонтик, расширение торговли, получение технологий и инвестиций, а также общее культурно-языковое пространство коммуникации.

Не следует абсолютизировать взгляды Дж. Коломера и других теоретиков малых государств, о которых речь пойдет ниже. При взгляде на современные процессы международных отношений и регионализации очевидно, что “включение" может принимать различные формы, как более явные, а именно - присоединение к торгово-экономическим и военно-политическим блокам, так и более размытые: вовлечение в культурно-языковые и торговые пространства без четких политических обязательств, позволяющих малому государству балансировать между несколькими крупными игроками, играя на сталкивающихся интересах и интернационализируя рискиํㅡㄴ.

В Прибалтике данная проблематика выражается, в первую очередь, в получении военных гарантий от НАТО и доступе к рынку и структурным фондам ЕС, усилении контроля скандинавского и немецкого капитала в финансовой и банковской сфере прибалтийских государств, декларировании элитами приверженности евроатлантическим ценностям.

Тенденции отмеченной зависимости усиливаются современными процессами глобализации и регионализации. С одной стороны, значение мировой торговли резко возросло, ускорились коммуникации и усилились трансграничные угрозы. С другой стороны, происходит регионализация, развитие экономических связей на региональном уровне, прежде всего в регионе Балтийского моря и ЕС. Частью этой тенденции выступает развитие транснациональных субъектов - как разного рода общественных организаций, так и транснациональных корпораций [Лебедева 2013], которые становятся важным фактором в расчетах национальных элит. Таким образом, понятие малого государства представляет первую точку отсчета для выработки теоретической рамки анализа прибалтийских властных групп.

В этой связи возникают два вопроса: во-первых, насколько сегодня обосновано понятие Прибалтика как категория научного анализа, учитывая существующие различия между Латвией, Литвой и Эстонией? Иными словами, обоснованно ли рассматривать кейс Прибалтики в целом или следует рассматривать каждую страну в отдельности? Во-вторых, в какой мере указанная теоретическая рамка малых государств и пространств-“империй” применима к прибалтийским государствам и какова региональная специфика институционализации и действий их политических элит?

Латвию, Литву и Эстонию по принципу географической близости, схожести их демографических, экономических и политических характеристик, а также исторического наследия можно отнести к одному субрегиону. На современном этапе эти страны демонстрируют заметные различия в плане социального развития, имеют ряд взаимных противоречий (преимущественно в экономической сфере). Вместе с тем их элиты придерживаются общих внешнеполитических приоритетов - проводят в отношении России схожую политику, исходящую из предпосылок сохраняющегося в постсоветский период недоверия, стремления к дистанцированию и нацеленности на относительно высокий уровень конфликтности в области политики, экономики и информационно-гуманитарной сфере.

\footnotetext{
${ }^{1}$ Примеры первого типа форм распространены в Европе, большинство стран которой входят в военный блок НАТО. Примеры второго можно найти в Юго-Восточной Азии, где основным региональным объединением является АСЕАН, а США присутствуют в регионе за счет двусторонних альянсов [см. Lee 2012].
} 
В рамках настоящей статьи под термином малая страна подразумевается государство, которое в силу ограниченности ресурсов неспособно в полной мере обеспечить свою военную и экономическую безопасность и вынуждено вступать в асимметричные отношения, полагаясь на поддержку крупных держав или межгосударственных объединений. Данное определение соответствует подходам П. Катценштейна [Katzenstein 2003] и Р. Ротстайна [Rothstein 1968]. Политическая система малой страны в силу ограниченности ресурсов испытывает существенное влияние экзогенных факторов. Подобная характеристика представляется в полной мере применимой к прибалтийским государствам: они входят в крупные политико-экономические и военно-политические объединения, географически находясь на стыке с альтернативными интеграционными и кооперационными структурами (НАТО и ОДКБ - союзы, а ЕС и ЕАЭС - экономические интеграторы), что подчеркивает их лимологическое положение. За последние десятилетия данные страны пережили глубокие внутренние трансформации. Особый интерес представляет процесс трансформации политической элиты в связи со сменой системы союзов, переориентацией властных групп стран Прибалтики в международной политике.

Политические элиты стран Прибалтики были “встроены” в систему СССР, затем пережили период выхода и встали на путь интеграции в евроатлантический блок. Данный исторический аспект наложил на исследование элит не только в Прибалтике, но и в Восточной Европе особый отпечаток: как правило, они рассматривались в контексте транзитологической парадигмы, теории демократизации, в широком смысле - различных ответвлений теории модернизации как перехода к более развитым формам политической системы. В этом теоретическом русле укрепилось представление о политических элитах как “драйверах" смены режимов в процессе посткоммунистических трансформаций Восточной Европы. При этом переходы к демократии интерпретировались в первую очередь как “пакты элит" о передаче власти и ее “распределении”. Внимание исследователей длительное время привлекали именно аспекты смены политических элит. В прибалтийских государствах можно выделить несколько “волн”, этапов смены элит.

Во-первых, это приход во власть так наз. политиков морали - преимущественно гуманитарной интеллигенции, что во многом характерно для Восточной Европы в целом. Эти группы выступали выразителями идеологии “перехода от коммунизма к демократии"; значительную роль сыграли факторы исторической политики. В Прибалтике это - попытка “изобрести” преемственность с довоенными режимами (доктрина континуитета), а также пропаганда специфического набора исторических мифов, в центре которых находится миф о “советской оккупации” [Сафроновас 2009].

По мере развития рыночных отношений и приватизации обозначилась вторая “волна" - в состав политической элиты начали входить представители бизнеса [Steen, Ruus 2002: 223-248]. При этом в элите сохранялись номенклатурные кадры. Произошло выдвижение кадров среднего звена на более высокие властные позиции, тогда как крупные политические руководители эпохи заката коммунистических режимов ушли из высших эшелонов власти. Процесс замещения “политиков морали” технократами из номенклатуры был продиктован объективными потребностями перехода от политической мобилизации и переформатирования политической системы к регулированию распределения ресурсов и управлению новой экономикой [Bozoki 2003; Szelenyi, Szelenyi 1995]. 
Многочисленные исследования показали, что всеобъемлющей смены элиты после крушения коммунистических режимов не произошло, многие прежние кадры сохранили свои позиции и во властных кругах “новых" обществ. Основной механизм заключался в конвертации “капиталов": культурного - в политический, политического - в экономический и т.д. ${ }^{2}$

Данные волны изменения состава властных групп - распространенная схема трансформации элитного рекрутирования в Восточной Европе в посткоммунистический период [Wasilewski 2001]. Отличительной чертой этого процесса в странах Прибалтики выступает тот факт, что важную роль в становлении независимости Литвы, Латвии и Эстонии, их внешнеполитической переориентации на евроатлантический блок, сыграла незначительная в количественном отношении, но важная с точки зрения принятия стратегических решений группа - представители зарубежной диаспоры. Выходцы из США и Канады были президентами Латвии, Литвы и Эстонии, занимали ключевые позиции в парламентах, службах безопасности, армии, на дипслужбе 3 .

Следует отметить, что каналы и механизмы элитного рекрутирования в странах Прибалтики после провозглашения независимости во многом определялись логикой инструментального использования фактора "наследия прошлого”. И если в период “политиков морали” эти тенденции были объяснимы, то затем начался период их институционализации, несмотря на то, что наиболее яркие публичные сторонники данных идей постепенно ушли с властных позиций. Речь идет, прежде всего, о противопоставлении современного и советского периодов литовской, латвийской и эстонской истории. Кроме того, следует отметить и рекрутирование выходцев из зарубежного диаспорального сообщества. Влияние этого фактора на процессы элитогенеза в странах Прибалтики, где одним из ключевых внутриэлитных расколов долго оставалось разделение на “посткоммунистов” и “антикоммунистов” (впоследствии переросшее в разделение по отношению к России в целом), сохраняется и по сей день. Латвийские ученые Б. Зепа и И. Супуле приходят к выводу, что политические элиты “по-прежнему используют этничность для того, чтобы привлекать сторонников на выборах. Таким образом, именно политики становятся основным катализатором усиления этнической напряженности".

Проблема заключается в том, что теория демократизации и парадигма транзитологии не дают четкого ответа на вопрос о том, как объяснить воз-

\footnotetext{
2 Данный вывод был сделан исследователями на основе развития идеи П. Бурдье о различных типах социальных капиталов и наиболее полно изложен в работах Э. Ханкисс [Hankiss 1991; Bourdieu 1986].

${ }^{3}$ Среди выходцев из диаспорального сообщества, попавших в политическую элиту Латвии, - paботавшая в американских учреждениях и жившая в США гражданка Канады В. Вике-Фрейберга (в 1999 г. избрана президентом Латвии), уроженец США Н. Муйжниекс (в 2002 г. назначен министром по делам общественной интеграции), выросший в США О. Калниньш (посол Латвии в США в 1993-1999 гг., впоследствии возглавлявший комитет по международным делам сейма Латвии), уроженец Великобритании, где дослужился до звания бригадного генерала, Я. Кажоциньш (глава контрразведывательной службы Бюро по защите Конституции Латвии), В. Павловскис (министр обороны в 1993-1995 гг.) и др. В случае Эстонии примером представителя зарубежной диаспоры в политике является президент Т.Х. Ильвес, родившийся в Швеции и выросший в США. Среди наиболее известных выходцев из литовского диаспорального сообщества - В. Адамкус, который дважды становился президентом Литвы; председатель Инвестиционного банка Литвы, член Сейма и впоследствии министр финансов В. Дуденас, вице-спикер сейма Ф. Палубинскас, кроме того, советник спикера сейма В. Ландсбергиса Т. Климас (бывший сотрудник ФБР), который руководил его кампанией во время президентских выборов 1997 г. и др. [Смирнов 2016].
}

4 Зепа Б. 2005. Латвийская субмарина. - Эксперт Северо-Запад. 12-18 сентября. № 34. С. 9. 
никшую систему политических отношений в прибалтийских государствах, а также спрогнозировать ее развитие с позиций выявления коридора доступных альтернатив для будущих политических решений властных групп. И это ключевая проблема в анализе при переходе властных групп от периода их трансформации в 1990-2000-х годах к новейшему этапу их развития.

В западной литературе и отчетах международных организаций прибалтийские страны признаются демократическими, успешными "кейсами транзита”. Формально правила и стандарты евроатлантического сообщества были приняты прибалтийскими элитами, созданы соответствующие формальные институты. Вместе с тем на практике проявился целый ряд проблем и несоответствий. Так, в 1992-1994 гг. СБСЕ / ОБСЕ выступила оператором на переговорах и гарантом вывода российских войск из стран Прибалтики. В сферу ее ответственности в странах Прибалтики также входило содействие соблюдению прав национальных меньшинств и принятию соответствующего законодательства о гражданстве. Несмотря на это, в начале 2000-х годов полевые миссии ОБСЕ в Эстонии и Латвии были закрыты без консенсусного решения Постоянного совета ОБСЕ 5 .

Это означало формальное признание отсутствия проблем с правами человека, несмотря на протесты национальных меньшинств в Латвии и Эстонии и принципиальную нерешенность проблем их правового статуса. Вывод миссий ОБСЕ был необходимым формальным шагом на пути к дальнейшей евроатлантической интеграции обществ, а властные группы в своем большинстве выбрали именно этот вектор.

Данный эпизод дополняется целым рядом шагов властных групп, прежде всего во внутренней политике стран Прибалтики. Например, сохранение статуса “неграждан” в Латвии и Эстонии, ущемляющего его обладателей в целом ряде политических и экономических прав, или криминализация на законодательном уровне отрицания “советской оккупации” в Литве и Латвии.

При этом следует отметить, что русскоязычное меньшинство в Латвии и Эстонии неоднородно: в нем присутствуют носители различной идентичности, по-разному относящиеся к самоотождествлению с титульной нацией и выступающие носителями различных политических взглядов ${ }^{6}$. Очевидная внутренняя дифференциация национальных меньшинств не отменяет проблематики формирования институтов, фактически исключающих значительные национальные меньшинства из политической жизни в Латвии и Эстонии. В Литве, в свою очередь, достаточно остро стоит проблема польского меньшинства, являющаяся одним из камней преткновения в литовско-польских отношениях.

Темы “советского прошлого" и “угрозы с Востока" стали традиционными инструментами для борьбы находящихся у власти элитных групп с конкурирующими политическими силами внутри стран Прибалтики. Неотъемлемой частью сложившейся новой модели элитной организации стал дискурс секьюритизации, поддерживающий внутреннюю однородность властных групп

\footnotetext{
${ }^{5}$ Выступление Постоянного Представителя России при ОБСЕ А.Ю. Алексеева на заседании Постоянного Совета ОБСЕ 18 декабря 2001 г. Доступ: http://www.osce.org/ru/pc/18160?download=true (проверено 17.08.2017).

${ }^{6}$ См. напр. исследование Латвийского университета “Этническое и нарративное разнообразие в конструкциях историй в жизни Латвии” [Все мы дети... 2016].
} 
[Andžāns 2014]. Не менее важно и изучение комплекса вопросов, связанных с неформальными институтами в управлении политической и экономической системами прибалтийских стран [Смирнов 2016].

Налицо проблема: транзитологическая парадигма рассматривает политические процессы как движение из заданной точки “A” в точку “Б”, при этом упуская реальную специфику и нивелируя возможности анализа политических процессов за рамками заранее заданных нормативных акцентов и ограничений [Капустин 2001]. Отмеченные действия прибалтийских элит не укладываются в рамки транзитологии и теории демократизации. Следовательно, возникает необходимость в расширении теоретико-методологического инструментария. Рассмотрим подробнее ряд ключевых решений элит прибалтийских государств в сфере политики и экономики на современном этапе.

Важным элементом сложившейся модели элитной организации прибалтийских государств стал дискурс "секьюритизации" - использование аргументов о защите от "российской угрозы" для консолидации внутренней поддержки вступления в ЕС и НАТО, а также для укрепления переговорной позиции с западными элитами. Как отмечает М. Малксоо, “постоянные апелляции к истории делают возможным позиционирование себя как жертвы России и безразличия Европы... [дают возможность] поставить ЕС в позицию должника Прибалтики. Это позволяет не только настаивать на получении необходимой политической и экономической поддержки, но также претендовать на включение интересов прибалтийских государств во внешнюю политику EC" [Malksoo 2006: 289].

Итогом стала выработка и прочное закрепление в политическом дискурсе темы Прибалтики как “форпоста" Запада на границах с “восточным соседом”. Руководство Литвы официально объявило о намерении построить стену на границе с Калининградской областью. На границе России и Латвии стена строится с 2015 г., она должна быть завершена к 2019 г. (длина 193 км). Свою стену возводит и Эстония, планируя достроить ее к 2018 г.

Процесс секьюритизации предполагает активное участие специальных служб в публичной жизни государства и общества. Анализ данной проблематики выходит за рамки настоящей статьи; приведем лишь несколько примеров, характеризующих ситуацию. Так, Департамент полиции безопасности Эстонии (КаПо) периодически публикует открытые доклады, обозначающие на персональном уровне так наз. врагов государства. Также существует практика проведения КаПо регулярных закрытых семинаров для учителей обществознания в Эстонии 7 . В Литве методы специальных служб в общественно-политической сфере во многом схожи. Например, ежегодные доклады Департамента госбезопасности, которые активно продвигаются в СМИ и в основном посвящены отражению “угрозы с Востока". Аналогичные доклады, указывающие на “нелояльные элементы” в политических, медиа и правозащитных кругах, выпускаются и латвийскими специальными службами - Бюро по защите Конституции и Полицией безопасности МВД.

Характерной чертой политического процесса в прибалтийских государствах выступает существенная, временами гипертрофированная роль политики памяти, институционализация которой фактически завершилась. Под патро-

\footnotetext{
${ }^{7}$ Корнышева М. В обстановке особой секретности полиция безопасности продолжает наставлять учителей. - Delfi.ee. 19.03. Доступ: http://rus.delfi.ee/projects/opinion/v-obstanovke-osoboj-sekretnostipoliciya-bezopasnosti-prodolzhaet-nastavlyat-uchitelej?id=71046951 (проверено 17.07.2017).
} 
натом государства созданы специализированные институты, музеи, комиссии, продвигающие конкретную интерпретацию событий национальной истории ${ }^{8}$. Национальные парламенты инициировали создание комиссий по подсчету ущерба от “советской оккупации". “Наследие коммунизма” становится универсальным внутриполитическим ответом элит на проблемы в экономике и институциональном развитии. Но это еще и способ примирить демократическую идеологию, необходимую элитам для интеграции в евроатлантическое сообщество, и государственный этнонационализм, исключающий национальные менышинства из политического процесса (институт “неграждан” в Латвии и Эстонии, проблема польского меньшинства в Литве) ${ }^{10}$.

Можно предположить, что политика памяти играет вспомогательную роль для обоснования ряда исключающих национальные менышинства институтов и “секьюритизации". Однако со временем она приобрела относительно самостоятельную логику развития в связи с настойчивыми и небезуспешными попытками участия элит прибалтийских стран в формировании общеевропейской политики памяти и экспорте своих практик в этой сфере в другие регионы (например, в Украину). Тема “советской оккупации” стала своеобразным маркером в рамках элитных групп, позволяющим провести черту между сторонниками властных режимов и “другими”, тем самым способствуя консолидации правящей элиты.

Отмеченные факторы начинают оказывать влияние на экономическое развитие стран Прибалтики. Как подчеркивает Марис Анджанс, главной сферой секьюритизации в отношениях прибалтийских государств с Россией выступает энергетика [Andžāns 2014], прежде всего в газовой и электроэнергетической сфере. Так, страны Прибалтики взяли курс на полный выход из энергосистемы БРЭЛЛ. Литва отказалась не только от участия в проекте строительства, но и от транзита электроэнергии Балтийской АЭС в Калининграде ${ }^{11}$. Аналогичная позиция принята в отношении Белорусской АЭС, возводимой в Островце. Страны Прибалтики отказались от присоединения к газопроводу “Северный поток” и активно выступают против “Северного потока-2". Участие в указанных проектах могло бы существенно снизить цены на энергию, а неучастие обернулось упущенной выгодой, особенно учитывая, что по прогнозам западных аналитиков к 2030 г. потребности

\footnotetext{
${ }^{8}$ Перечислим лишь наиболее известные учреждения: Центр исследования геноцида и резистенции жителей Литвы, Комиссия по истории при президенте Латвии, Эстонский институт исторической памяти. Музеи “нацистской и советской оккупации” созданы в Литве, Латвии и Эстонии и их посещение постоянно вносится в программы визитов западных политиков. В 2013 г. после восьмилетнего перерыва по указу президента Литвы Д. Грибускайте возобновила свою деятельность Международная комиссия по оценке преступлений нацистского и советского режимов в Литве.

${ }^{9}$ В Эстонии подсчет ущерба от “советской оккупации” начался еще в 1992 г. В Литве в 2000 г. сейм принял закон “О возмещении ущерба от советской оккупации”. В 2005 г. в соответствии с декларацией сейма Латвии начала работать комиссия по подсчету ущерба от “советской оккупации” в Латвии.

${ }^{10}$ На фоне присоединения Литвы, Латвии и Эстонии к ЕС активизировалась традиционная критика со стороны международных организаций, касающаяся массовых нарушений прав человека в прибалтийских государствах. С соответствующими докладами и заявлениями выступали профильные органы ООН, ОБСЕ, Совета Европы, ПАСЕ, Еврокомиссии, а также различные международные общественные правозащитные организации.

${ }^{11}$ При строительстве Балтийской АЭС Литве предлагалось выбрать для себя ту долю, которую она может себе позволить, исходя из своих финансовых возможностей, потребности в электроэнергии. Подробнее см. Дмитрий Баранов о решении Литвы отказаться от АЭС Висагинас. - AtomInfo.ru. 14.11.2012. Доступ: http://www.atominfo.ru/newsc/10650.htm (проверено 17.07.2017).
} 
Латвии и Литвы в природном газе возрастут вдвое по сравнению с 2013 г. (до 2 и 4 млрд куб. м в год соответственно) [Honore 2014].

В 2015 г. в клайпедском порту введен в эксплуатацию первый в Прибалтике терминал сжиженного природного газа (СПГ) мощностью до 4 млрд куб. м в год. Для приема СПГ Литва арендует танкер "Independence" за 68,9 млн долл. в год. Заключены контракты на поставку норвежского СПГ, однако его стоимость существенно превышает стоимость закупки газа у “Газпрома". В результате правительство Литвы вынуждено было обязать внутренних поставщиков закупать более дорогой СПГ, что привело к росту цен для конечных потребителей. Это ставит вопрос о рентабельности СПГтерминала, тогда как для норвежских поставщиков контракт исключительно выгоден. Компенсировать потери от проекта Вильнюс надеется путем организации реэкспорта СПГ в Латвию и Эстонию, но властные группы в этих государствах ставят своей целью строительство собственных СПГ-терминалов.

Большинство подобных проектов реализуются с декларируемыми целями обретения “независимости” и “отсоединения" стран Прибалтики от единой с Россией транспортной и энергетической системы, ликвидации, по выражению прибалтийских экспертов, “островного” положения стран Прибалтики в отношении энергосистемы EC [Grigas et al. 2013].

По оценкам российских исследователей, еще до введения ЕС санкций против России, активными сторонниками которых выступали политические элиты стран Прибалтики, ежегодно экономики прибалтийских государств теряли до 9-10\% от ВВП в результате упущенных доходов от российского транзита, инвестиций и взаимной торговли [Межевич, Шадурский, Грозовский 2013: 6]. В результате снижается долгосрочная конкурентоспособность, своеобразный “запас прочности” экономик прибалтийских государств, что стало очевидно с наступлением мирового финансового кризиса, имевшего тяжелые последствия для стран Прибалтики, которые политические элиты переложили на плечи населения, приводя в действие меры “жесткой экономии”. Примечателен вывод нобелевского лауреата по экономике П. Кругмана о том, что страны Прибалтики прошли мировой финансовый кризис в значительной степени благодаря выезду граждан на заработки в Европу, что снизило общий уровень безработицы в стране в посткризисный период восстановления ${ }^{12}$.

Попытка теоретической интерпретации отмеченных решений и процессов институционализации властных групп прибалтийских государств создает ряд противоречий при применении как теории транзитологии, так и теории малых стран в трактовке Дж. Коломера. Политические элиты прибалтийских государств, присоединившись к евроатлантическому блоку, проводят собственную активную политику, которая далеко не всегда соответствует не только признанным трансатлантическим канонам демократического общества, но и демонстрирует тенденции к внешнеполитической регионализации, формированию специфических институтов, присущих прибалтийским государствам - как во внутренней, так и во внешней политике. Латвия, Литва и Эстония обладают различной структурой экономики и внешней торговли, сохраняют значимые политические и культурные различия. Вместе с тем их политика секьюритизации в отношении России и использование ее в каче-

\footnotetext{
${ }^{12}$ Krugman P. Baltic Brouhaha. - New York Times. 01.05.2013. URL: https://krugman.blogs.nytimes. com/2013/05/01/baltic-brouhaha/?_r=0 (accessed 21.03.2017).
} 
стве инструмента внутриполитического управления и внешнеполитического маневрирования в рамках евроатлантического блока является общей для политических элит всех трех государств при всех их особенностях.

Продуктивным может оказаться применение понятия институционального регионализма [Börzel 2011; Бусыгина 2001] элит как специфической характеристики структурной и субъектной динамики институционализации политических элит малых стран (субрегиона), обусловленной сопряженностью эндогенных и экзогенных (по отношению к политической системе) факторов. Политические элиты в процессе институционализации, испытывая существенное влияние экзогенных факторов, вырабатывают собственные подходы к внешнеполитической среде, что определяет вариативы их субъектности и поведения. Институциональный регионализм элит часто выражается в поиске решений внутренних задач в связи с внешними ресурсами, в том числе за счет актуализации субрегиональной коллаборации.

В теоретическом фокусе вновь оказывается переплетение конкретных решений властных групп во внутренней и внешней политике и, с другой стороны, структурных предпосылок и последствий этого выбора, формирующих эффект колеи (path-dependence). Закладывая миф об “оккупации” в символический фундамент новой государственности, политические элиты прибалтийских государств создавали предпосылки для дальнейшей институционализации подобной исторической политики, что проявилось как на организационном, так и на законодательном уровнях. Такая постановка вопроса отсылает к корпусу работ, посвященных морфогенетическому подходу в общественных науках [Archer 2004], основанному на идеях Э. Гидденса о “дуальности” агентов и структур, развитых учеными М. Арчер и У. Сьюэллом [Sewell 2009].

Применяя данные теоретические разработки к изучению элит, можно сформулировать следующие тезисы. Во-первых, структура функционирует как ограничитель действий элит. В любой период политической истории современных стран Прибалтики властные группы находились в определенном коридоре возможностей, заданном доступными ресурсами - как внутри, так и за границами государств. С другой стороны, структура дает элитам пространство для маневра. Опираясь на доступные ресурсы, организации и схемы представлений о мире, элиты определяют свои цели и борются за их достижение. Здесь уместно обратить внимание на практики концептуализации понятия внешнеполитического менталитета (на контрасте с внутриполитическим), акцентирующего идеальные компоненты, влияющие на линию действий политической элиты, исходя из самоидентификации по отношению к окружающему миру [см. напр. Чугров 2007].

Подводя итог, отметим, что региональный институционализм не может быть противопоставлен транзитологии или теории малых стран при изучении политических элит прибалтийских стран; скорее, он дополняет их, позволяя теоретизировать фактологический материал, противоречащий данным теориям. Страны Прибалтики во многом развивались в русле общих для региона Восточной Европы тенденций - как в плане трансформации структуры политических элит, так и их институционализации на внутриполитическом и внешнеполитическом уровнях. Вместе с тем кейс прибалтийских государств характеризуется более выраженными, чем в остальных странах Восточной Европы и Балтийского региона, процессами институционализации в сфере секьюритизации и исторической политики. 
В совокупности со спецификой географического положения прибалтийских стран на стыке двух интеграционных проектов Запада и Востока, а также их этнического состава и истории политической институционализации в постсоциалистический период действия их политических элит складываются в особую внешнеполитическую нишу, региональную функционализацию субрегиона Прибалтики, в которой ярко выражены элементы конфликтности и секьюритизации в отношении России, использующиеся для позиционирования властных групп прибалтийских государств в рамках евроатлантического сообщества. Подобная региональная специфика Прибалтики, выражающаяся в действиях властных групп, не может рассматриваться как универсальный пример для теории малых стран, но должна быть учтена как в ее рамках, так и в теории элит с точки зрения зависимости правящей когорты от экзогенных факторов.

Бусыгина И.М. 2001. Политическая роль регионов в структуре Европейского Союза: Концептуальные и прикладные аспекты. М.: МГИМО МИД России. 310 с.

Все мы дети своего времени: Истории жизни русских в Латвии. 2016. Под ред. Н. Пазухиной, И. Гарда-Розенберги. Институт философии и социологии Латвийского университета. $411 \mathrm{c.}$

Капустин Б.Г. 2001. Конец “транзитологии”? (О теоретическом осмыслении первого посткоммунистического десятилетия). - Полис. Политические исследования. № 4. C. 6-27.

Лебедева М.М. 2013. Акторы современной мировой политики: тренды развития. Вестник МГИМО-Университета. №1(28). С. 38-41.

Межевич Н.М., Шадурский А.В., Грозовский А.М. 2013. Отношения России и стран Прибалтики: от упущенных возможностей к реальным перспективам. СПб.: СПбГУ. 86 с.

Сафроновас В. 2009. О тенденциях политики воспоминания в современной Литве. - Ab Imperio: Studies of New Imperial History and Nationalism in the Post-Soviet Space. № 3. P. 424-458.

Смирнов В.А. 2016. Политические элиты Латвии, Литвы и Эстонии: факторы рекрутирования и структурная динамика. Калининград: Издательство Балтийского федерального университета им. И. Канта. 181 с.

Чугров С.В. 2007. Понятие внешнеполитического менталитета и методология его изучения. - Полис. Политические исследования. № 4. C. 46-65. DOI: https://doi. org/10.17976/jpps/2007.04.04

Andžāns M. 2014. Securitization in Defining Regional Security Complexes: the Case of the Baltic States. Riga: Rīga Stradinš Universit. 39 p.

Archer M. 2004. Being Human: the Problem of Agency. Cambridge University Press. 336 p.

Börzel T.A. 2011. Comparative Regionalism: A New Research Agenda. KFG Working Paper. No. 28. 38 p. URL: http://userpage.fu-berlin.de/kfgeu/kfgwp/wpseries/ WorkingPaperKFG_28.pdf (accessed 17.07.2017).

Bourdieu P. 1986. The Forms of Capital. - Handbook of Theory and Research for the Sociology of Education. Ed. by J.G. Richards. New York: Greenwood Press. P. 241-258.

Bozoki A. 2003. Theoretical Interpretations of Elite Change in East Central Europe. Elite Configurations at the Apex of Power. Ed. by M. Dogan, M. Leiden. Brill. P. 215-223.

Colomer J. 2007. Great Empires, Small Nations. The Uncertain Future of the Sovereign State. Routledge. 114 p.

Grigas A., Kasekamp A. Maslauskaite K., Zorgenfreija L. 2013. The Baltic States in the EU: Yesterday, Today and Tomorrow. Berlin: Jacques Delors Institute. 100 p. 
Hankiss E. 1991. Reforms and the Conversion of Power. - Upheaval against the Plan: Eastern Europe on the Eve of the Storm. Ed. by P. Weilemann, G. Brunner, R. Tokes. Oxford: Berg. P. 27-39.

Honore A. 2014. The Outlook for Natural Gas Demand in Europe. Oxford: Oxford Institute of Energy Studies. 174 p. URL: https://pdfs.semanticscholar.org/ed32/533e73e4b8e16f53ccb585b639264fc64f96.pdf (accessed 02.08.2017).

Katzenstein P.J. 2003. Small States and Small States Revisited. - New Political Economy. Vol. 8. No. 1. P. 9-30. DOI: https://doi.org/10.1080/1356346032000078705

Lee J. 2012. Hedging against Uncertain Future: The Response of East Asian Secondary Powers to Rising China. URL: http://rc41.ipsa.org/public/Madrid_2012/lee.pdf (accessed 17.07.2017).

Malksoo M. 2006. From Existential Politics Towards Normal Politics? The Baltic States in the Enlarged Europe. - Security Dialogue. Vol. 37. No. 3. P. P. 275-295.

Rothstein R. 1968. Alliances and Small Powers. New York. x+331 p.

Sewell W.H. 2009. Logics of History: Social Theory and Social Transformation. University of Chicago Press. 376 p.

Steen A., Ruus J. Change of Regime - Continuity of Elites? The Case of Estonia. - East European Politics and Societies. 2002. Vol. 16. No. 1. P. 223-248.

Szelenyi I., Szelenyi S. 1995. Circulation of Reproduction of Elites During the Postcommunist Transformation of Eastern Europe. - Theory and Society. Vol. 24. No. 5. P. 615-638. DOI: https://doi.org/10.1007/BF00993400

Wasilewski J. 2001. Three Elites of the Central-East European Democratization. Transformative Paths in Central and Eastern Europe. Ed. by R. Markowski, E. Wnuk-Lipinski. Warsaw: Institute of Polish Studies. P. 133-142.

DOI: $10.17976 / j p p s / 2017.05 .06$

\title{
THEORETICAL AND METHODOLOGICAL ASPECTS OF POLITICAL ELITES' INSTITUTIONALIZATION IN THE BALTIC STATES
}

\author{
V.A. Smirnov ${ }^{1}$ \\ ${ }^{1}$ Immanuel Kant Baltic Federal University. Kaliningrad, Russia
}

SMIRNOV Vadim Anatol'evich, Cand. Sci. (Pol. Sci.), Senior Researcher, Immanuel Kant Baltic Federal University. Email: vsmirnov@kantiana.ru

Smirnov V.A. Theoretical and Methodological Aspects of Political Elites' Institutionalization in the Baltic States. - Polis. Political Studies. 2017. No. 5. P. 79-90. (In Russ.) DOI: https://doi.org/10.17976/jpps/2017.05.06

Received: 30.01.2017. Accepted: 20.06.2017

\begin{abstract}
The article deals with theoretical and methodological aspects of elite study in the Baltic states on the basis of small states and regional studies. The special features of genesis and development of power groups in the region are deduced. The problem of theoretical correspondence between structural and subject aspects of study of political elite is considered. Emphasis is put upon the problem of juncture between domestic and foreign policy factors influencing political elite decisions. One of the starting points is theory of small states through the lens of which the main features of power groups development in the Baltic region are investigated. Small size of a state produces high dependency of political elites is Lithuania, Latvia and Estonia on foreign factors or, using terminology of Joseph Colomer, contemporary "empires" which structure transnational space. Special attention is paid to the historical factors in the genesis of political elite after the Baltic states left the Soviet Union. The article problematizes transitology paradigm, which is prevalent in the studies of this period in the Baltic states and in Eastern Europe as a whole. Besides the imperatives of regime change and transformation towards democratic ideals it is important to consider the imperatives of competition between power groups for resources in domestic and foreign political environment. Few contradictions are emphasized, i.e. the liquidation of OSCE missions in Latvia and Estonia, development of institutions of memory politics,
\end{abstract}


criminalization of the denial of "Soviet occupation". These are the instances of political elite decision on different stages of political regimes genesis in the Baltic states which are not fit into the logics of theory of democratization. On the basis of these theoretical assumptions various methods of elite studies are considered. The article proposes a theoretical framework of institutional regionalism which is presumed as more efficient as means of power groups studies in the Baltic states.

Keywords: political elite; power groups; political institution; institutionalization; structure; Baltic states.

\section{References}

Andžāns M. Securitization in Defining Regional Security Complexes: the Case of the Baltic States. Riga: Rīga Stradin̄̌s Universit. 2014. 39 p.

Archer M. Being Human: the Problem of Agency. Cambridge University Press. 2004. 336 p.

Börzel T.A. Comparative Regionalism: A New Research Agenda. KFG Working Paper. No. 28. 2011. 38 p. URL: http://userpage.fu-berlin.de/kfgeu/kfgwp/wpseries/WorkingPaperKFG_28.pdf (accessed 17.07.2017).

Bourdieu P. The Forms of Capital. - Handbook of Theory and Research for the Sociology of Education. Ed. by J.G. Richards. New York: Greenwood Press. 1986. P. 241-258.

Bozoki A. Theoretical Interpretations of Elite Change in East Central Europe. - Elite Configurations at the Apex of Power. Ed. by M. Dogan, M. Leiden. Brill. 2003. P. 215-223.

Busygina I.M. Politicheskaja rol' regionov v strukture Evropejskogo Sojuza: Konceptual'nye i prikladnye aspekty [Political Role of Regions in the Structure of the European Union: Conceptual and Practical Aspects]. Moscow: MGIMO. 2001. 310 p. (In Russ.)

Chugrov S.V. The Notion of Foreign Policy Mentality and Methodology of Its Study. - Polis. Political Studies. 2007. No. 4. P. 46-65. (In Russ.) DOI: https://doi.org/10.17976/jpps/2007.04.04

Colomer J. Great Empires, Small Nations. The Uncertain Future of the Sovereign State. Routledge. 2007. 114 p.

Grigas A., Kasekamp A. Maslauskaite K., Zorgenfreija L. The Baltic States in the EU: Yesterday, Today and Tomorrow. Berlin: Jacques Delors Institute. 2013. 100 p.

Hankiss E. Reforms and the Conversion of Power. - Upheaval against the Plan: Eastern Europe on the Eve of the Storm. Ed. by P. Weilemann, G. Brunner, R. Tokes. Oxford: Berg. 1991. P. 27-39.

Honore A. The Outlook for Natural Gas Demand in Europe. Oxford: Oxford Institute of Energy Studies. 2014. 174 p. URL: https://pdfs.semanticscholar.org/ed32/533e73e4b8e16f53ccb585b639264fc64f96.pdf (accessed 02.08.2017)

Kapustin B.G. The End of "Transitology"? (Reflecting on the First Post-Communist Decade as Subject of Theoretical Interpretation). - Polis. Political Studies. 2001. No. 4. P. 6-27. (In Russ.)

Katzenstein P.J. Small States and Small States Revisited. - New Political Economy. 2003. Vol. 8. No. 1. P. 9-30. DOI: https://doi.org/10.1080/1356346032000078705

Lebedeva M.M. Actors of Contemporary World Politics: Trends of Development. - Vestnik MGIMOUniversity. 2013. Vol. 1. No. 28. P. 38-41. (In Russ.)

Lee J. Hedging against Uncertain Future: The Response of East Asian Secondary Powers to Rising China. 2012. URL: http://rc41.ipsa.org/public/Madrid_2012/lee.pdf (accessed 17.07.2017).

Malksoo M. From Existential Politics Towards Normal Politics? The Baltic States in the Enlarged Europe. - Security Dialogue. 2006. Vol. 37. No. 3. P. P. 275-295.

Mezhevich N.M., Shadurskij A.V., Grozovskij A.M. Otnoshenija Rossii i stran Pribaltiki: ot upushhennyh vozmozhnostej k real'nym perspektivam [Relations between Russian and Baltic States: from Lost Opportunities towards Realistic Prospects]. Saint Petersburg: Saint Petersburg State University. 2013. 86 p. (In Russ.)

Rothstein R. Alliances and Small Powers. New York. 1968. x+331 p.

Safronovas V. On Treand in Memory Politics in Modern Lithuania. - Ab Imperio: Studies of New Imperial History and Nationalism in the Post-Soviet Space. 2009. № 3. P. 424-458. (In Russ.)

Sewell W.H. Logics of History: Social Theory and Social Transformation. University of Chicago Press. 2009. $376 \mathrm{p}$.

Smirnov V.A. Politicheskie jelity Latvii, Litvy i Jestonii: faktory rekrutirovanija i strukturnaja dinamika [Political elites of Latvia, Lithuania, Estonia: Factors of Recruitment and Structural Dynamics]. Kaliningrad: Izdatel'stvo Baltijskogo federal'nogo universiteta im. I. Kanta. 2016. 181 p. (In Russ.)

Steen A., Ruus J. Change of Regime - Continuity of Elites? The Case of Estonia. - East European Politics and Societies. 2002. Vol. 16. No. 1. P. 223-248.

Szelenyi I., Szelenyi S. Circulation of Reproduction of Elites During the Postcommunist Transformation of Eastern Europe. - Theory and Society. 1995. Vol. 24. No. 5. P. 615-638. DOI: https://doi.org/10.1007/ BF00993400

Vse my deti svoego vremeni: Istorii zhizni russkih v Latvii [We are All Children of Our Times: Stories from Lives of Russians in Latvia]. Ed. by N. Pazuhina, I. Garda-Rozenberg. Institut filosofii i sociologii Latvijskogo universiteta. 2016. 411 p. (In Russ.)

Wasilewski J. Three Elites of the Central-East European Democratization. - Transformative Paths in Central and Eastern Europe. Ed. by R. Markowski, E. Wnuk-Lipinski. Warsaw: Institute of Polish Studies. 2001. P. 133-142. 